\title{
UNA NOTA BIOGRÁFICA DE CIDI HAMETE BEN GELIE*
}

AHMED ABI-AYAD

Universidad de Orán

Miguel de Cervantes Saavedra, héroe de la batalla de Lepanto, es un gran conocedor del mundo y la cultura árabe-musulmana.

Vencedor de la Goleta en Túnez, se encontró más tarde, en 1575, encarcelado en los baños de Argel, donde pasó cinco largos años de penas y sufrimientos ${ }^{1}$, pero, también y sobre todo, de amores. Adquirió una gran formación, y conocimientos diversos y sólidos, en dicha cosmopolita ciudad argelina, capital mediterránea de no menos de cien mil habitantes y más o menos poblada y animada que Nápoles. Su condición de cautivo de rescate le ofrecía muchas facilidades y un cierto grado no pequeño de libertad, que aprovechaba para pasear por la ciudad y realizar así, tranquilamente, sus repetidos y fracasados intentos de evasión. Todas estas peripecias de su estancia argelina son narradas

* Extracto de una comunicación presentada al III Coloquio Internacional de la Asociación de Cervantistas (Argamasilla de Alba, 1995) bajo el título *Homenaje a Cidi Hamete Ben Gelie a Miguel de Cervantes».

1 «Les Maures étaint plus humains avec leurs esclaves que les Européens avec leurs domestiques»: TUBert Delof, G. (1974): L'Afrique Barbaresque. Genève: Droz, p. 118. Anota también Clemencín: «Probablemente en aquella epoca no se hubiera permitido otro tanto a los moros cautivos en Espaniaw. 
en su obra, que el sagaz lector podrá descubrir e interpretar de la mejor manera posible, siempre -eso sí- teniendo en cuenta los desvíos y maniobras estilísticas de Cervantes para desorientar y evitar los riesgos de la severa censura inquisitorial de su época ${ }^{2}$.

Después de su rescate en 1581 regresó a España, y un año más tarde efectuó un misterioso viaje a Orán como correo del rey Felipe II ante el alcalde de Mostaganem ${ }^{3}$, en cuyo transcurso «entró en directa relación con notables maestros de la fraternidad sufí, que lo iniciaron en ejercicios místicos de interiorización y en el conocimiento de venerables doctrinas desconocidas por el vulgo». Durante este viaje tuvo también discusiones con los militares españoles establecidos en las plazas fuertes de Orán, y se entero ampliamente de la situación bélica y militar que conocía esta región, expuesta constantemente a los ataques y asedios oraneses para liberar la ciudad 4 .

Esta rica y fructuosa estancia argelina de Cervantes, de la cual poco se ha escrito e interpretado con imparcialidad, le dio finalmente la oportunidad de observar, convivir con y comprender a las gentes y culturas diferentes, en medio de un ambiente atractivo que favorecía el conocimiento de lenguas, hábitos y tantas otras cosas. La imagen que nos da del Argel contemporáneo es reveladora:

\author{
Argel es según barrunto \\ Arca de Noe, abreviada: \\ Aquí están de todas suertes, \\ Oficios y habilidades, \\ Disfrazadas cualidades ${ }^{5}$
}

${ }^{2}$ La cuidadosa lectura de lo dicho y no dicho en las páginas cervantinas nos lleva a señalar la siguiente afirmación de $P$. HAZARD con respecto a las actitudes que se tomaban frente a tal o cual asunto que preocupaba a la opinión espanola: el cauto Cervantes «désapprouve discrètement et approuve avec éciat...», como atributo a unos tiempos en que la hipocresía era necesaria para sobrevivir. Es sabido de todos que, p. ej., los elogios eran una obligación y constitúan además el único salvaconducto para cualquier discusión de gran importancia. Véase Don Quijote de Cervantes, Paris, 1949, p. 234.

${ }^{3}$ La vida del ilustre escritor, Miguel de Cervantes Saavedra, queda todavía mal conocida hasta hoy dí, puesto que ciertos elementos relacionados con su estancia argelina siguen oscuros, particularmente los que corresponden a su misterioso viaje a Orán y Mostaganem.

${ }^{4}$ El resultado de este viaje a Orán fue la producción de su comedia El gallardo español, basada en las informaciones recibidas allí, de parte de los comandantes de plazas españolas, sobre hechos de guerras y asedios, así como las procedentes de su propio y perspicaz análisis de la situación.

5 M. de Cervantes Saavedra: Los baños de Argel (ed. J. Canavaggio). Madrid: Taurus, 1984, p. 123. 
Clara alusión a la intensa actividad social, a la riqueza y variedad humana que se dedica hábilmente a sus diversas ocupaciones.

Otra estrofa ilustra esta atmósfera de diversidades humanas que practican distintas lenguas $y$, sin embargo, se comunican en una sola, casi común, que es la lengua franca:

Aquí todo es confusión, y todos nos entendemos, en una lengua mezclada que ignoramos y sabemos 6

Como se puede imaginar, Cervantes vivió entre árabes, musulmanes, cristianos, otomanos, moriscos, etc., que conocía perfectamente. Esta panoplia de tipos humanos que desfilaban ante él enriqueció su cultura, desarrolló su sentido de observación e impregnó hondamente su espíritu de tolerancia y humanismo; virtudes esenciales que Cervantes descubría y admiraba mucho en los musulmanes:

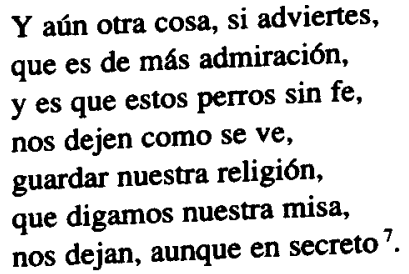

Este sentido de tolerancia y humanismo que Cervantes cultiva y propaga intensamente en su Quijote lo debe, sin duda, a la gran influencia islámica sufí de los musulmanes y, precisamente a la del notable morisco Cidi Hamete Ben Gelie, a quien atribuía la autoridad del libro.

¿Quién fue Cidi Hamete Ben Gelie?, ¿aquel historiador árabe que Cervantes honraba en su prólogo? El manuscrito andino, poco conocido, que descubri6 el historiador Enrique Tord representa tan grande importancia, que disipa la nebulosa polémica sobre el coautor del Quijote ${ }^{8}$.

6 fdem. Cervantes: La gran sultana.

7 M. de Cervantes: Los baños de Argel, op. cit., p. 129.

Vid. LoPEZ Navio, JosÉ (1960): "Cidi Hamete Bengelie" = Lope de Vega. BBMP. Cf. ENRIQUE TORD, L.: «Cidi Hamete Bengelie, coautor del Quijote». Conste aquí mi agradecimiento al Sr. Embajador Jaime Cáceres, quien hizo todo lo posible para que este artículo llegara a mis manos. 
El manuscrito revela que en 1602 Cidi Hamete Ben Gelie había compartido el mismo calabozo de la Real Cárcel de Sevilla con Miguel de Cervantes Saavedra, con quien había hecho honda amistad; y que en aquella época sevillana, bajo el nombre cristiano de Antón Gonzálvez, ocultaba su verdadera identidad: la de un morisco cristianizado, Hamete Ben Gelie; es decir, que él había sido aquel «historiador arábigo» que, según Cervantes, escribio el Quijote.

En este documento, Cidi Hamete Ben Gelie nos facilita más detalles acerca de su familia, respecto de la cual dice que era de moros conversos después de la impuesta cristianización. Subraya que, en la mayoría de los miembros de la familia, habían persistido prácticas espirituales de antigua ascendencia islámica «profesadas por algunos parientes que habían pertenecido a aquel selecto grupo de oficiales de caballería noble de los califas de Córdoba...»

La referencia a los ancestros cordobeses de cada cual y, sobre todo, las comunes aficiones intelectuales habían acercado de inmediato a estos dos hombres que el destino había arrojado a la prisión en medio de hombres zafios, torcidos y vulgares.

Dice Cidi Hamete que fue grande su satisfacción en el trato con Cervantes, pues día a día apareció en él «un alma sensible y generosa, plena de experiencia, y que, a pesar de su natural abatimiento por la circunstancia en que se veía envuelto, bullía en proyectos literarios de toda especie...» Pero lo que le impresionó mucho fue el fino y vasto conocimiento que tenía Cervantes de «aspectos velados e interiores del pensamiento místico islámico. Decía, por cierto, que buena parte de ese conocimiento lo había adquirido en Argel».

De las largas discusiones, resulta la siguiente valoración del propio Cidi Hamete: «sabiendo Cervantes de mi ascendencia islámica y sobre todo habiéndose percatado de inmediato de que yo tenía noticias serias acerca de aquellas prácticas místicas me confí con ardiente entusiasmo cómo sus conversaciones con aquellos nobles imames, lo había abierto a una comprensión inesperada del mundo espiritual que lo había hecho entender mejor la alta poesía espiritual de Santa Teresa y de San Juan de la Cruz. Pero especialmente precisa Cidi Hamete- fue como iluminado con las imágenes del juego de espejos que presenta la Realidad y acerca de cuyas sutiles implicaciones son verdaderos eruditos los ascéticos maestros de algunas fratemidades sufíes del norte de África».

Fue mediante esos intercambios como Hamete se dio cuenta de que Cervantes sintio crecer en él un irrefrenable deseo de componer una obra que describiera la vida del alma noble, asediada, agredida y burlada por las apariencias. Una obra humana, aferrada a la tragedia del mundo, de la existencia. Y, cuando lo veía gesticular con tanto ardor en la semipenumbra de la prisión -agregaba Hamete-, 
«entendía yo que en verdad hablada de un drama universal que era su propio drama, comprendido, iluminado, diría mejor por aquella perspectiva filosófica que habían sembrado en él los sutiles espirituales islámicos».

Luego de haber salido los dos de la prision, Cervantes emprendió viaje hacia Toledo, y el morisco, después de no pocas peripecias, sepultó para siempre su nombre - Cidi Hamete Ben Gelie-, trocándolo definitivamente por el de Antón Gonzálvez (con el que pasó con dudosos papeles a Hispaniola, México y, por último, a Sudamérica).

Allí viajó durante veinte años en el trajín de la venta de muy variada mercadería en las principales ciudades del inmenso virreinato. Y, en todo este largo lapso, no supo más de lecturas ni de amistades de literatos hasta que, ya de setenta y cinco años, sin familia y sin hijos, con una mediana fortuna entre las manos y gran desazón en el alma, decidio - tras dos años de reflexiones-ingresar en el convento franciscano y llamarse Fray Diego de la Santa Fe.

Pocos meses después fue cuando en la gran biblioteca de la orden había leído, con inefable sorpresa, la primera parte del Quijote de Cervantes en la edición príncipe madrileña de 1605 , llevada a los Andes por el librero Juan de Sarriá, al año siguiente de su impresión ${ }^{9}$.

Cuán grande fue el deslumbramiento y confusión de Fray Diego de Santa Fe al leer su oculto antiguo nombre, Cidi Hamete Ben Gelie, en obra de tanta resonancia. Rápidamente, añoró aquellos días de prisión en Sevilla con aquel hombre encantador - Cervantes-; quien, a pesar de que no se volvieron a ver en más ocasiones, lo había recordado honrándolo al hacerlo autor de esa obra asombrosa, tal como lo escribe en el capítulo IX de la primera parte del Quijote de esta manera: «estando yo un día en la calle Alcaná de Toledo, llegó un muchacho en vender unos cartapacios con caracteres que conocí arábigos... Anduve mirando si parecía por allí algún morisco aljamiado que los leyese, y no fue muy dificultoso hallar intérprete semejante... y, haciéndolo, volviéndolo de improviso el arábigo al castellano dijo que decía: "historia de Don Quijote de la Mancha, escrita por Cidi Hamete Ben Gelie, jistoriador arábigo"» 10 . $Y$, por si no fuera suficiente esta nota, Cervantes precisaba en su prólogo que él no era el padre del Quijote, sino su padrastro.

Esta noble y honrada actitud de Cervantes despertó aún más admiración y reconocimiento en Fray Diego de Santa Fe (o sea, Cidi Hamete Ben Gelie) al

- El autor, Tord, pudo comprobar y consultar el mismo libro del Quijote que ley6 Cidi Hamete Ben Gelie, quien afirma que sigue perfectamente bien conservado en aquella biblioteca.

10 M. de Cervantes Saavedra: Don Quijote de la Mancha. (Ed. 1971). Barcelona: Juventud, 1.' parte, cap. VI. 
descubrir en el Quijote la remota historia que le contaba antaño en la cárcel de Sevilla relativa a uno de los tíos del morisco sobre «el relato del caballero del Desierto a quien le ocurren mil y una aventuras de las cuales sólo algunas que había yo retenido transmití a Cervantes quien, desde aquella noche y por siete días más, escuchó embelesado».

En esencia, decía Fray Diego: «aquel caballero era uno de los modelos legendarios del inicio de las órdenes de caballería islámica, siendo la narración de sus aventuras una extensa alegoría de los diversos obstáculos o niveles del conocimiento que debe alcanzar - mediante la experiencia- el "peregrino armado» que viaja en busca de la Amada, es decir, de la Sabiduría».

La lectura del Quijote por Fray Diego a miles y miles de kilometros de su tierra natal resucitó sus sentimientos patrióticos y de identidad personal como aquellos recuerdos de interesantes y largos intercambios con Cervantes en la cárcel sevillana. Todo eso lo dejó muy atento y emocionado, como se aprecia en sus frases: «No puedo dejar de sentirme perplejo al constatar los cauces que toman los acontecimientos de la vida: la historia suff legendaria y remota de un Caballero del Desierto, narrada en mi niñez por un tío y transmitida muchos años después en una cárcel sevillana a un recién conocido, inspiró una obra inmortal. ¿Quién es el autor de ella?». Y agregaba Cidi Hamete, todavía imbuido de sus ejercicios espirituales heredados de sus ancestros mudéjares: «No hay duda de que aquel lúcido Cervantes estaba destinado a reflejar un aspecto sustantivo de la condición humana, cuya visión está permanentemente presente en los testimonios de los grandes místicos cristianos e islámicos».

No puedo dejar de referirme a estos últimos, pues Cervantes había sido alimentado por ellos y porque la semilla de su historia del Quijote había sido una alegoría fácil del viaje del alma y del peligroso juego de apariencias que es la realidad. Para Hamete, Cervantes estuvo profundamente impregnado de aquel espíritu alegórico y simbólico que era tan caro a los poetas místicos islámicos y que ello fue sustantivo en la formación literaria de un esclarecido humanista como Cervantes.

Termina Cidi Hamete sus referencias a Cervantes con esta espléndida y relevante afirmación: «Pocas veces se podrá explicar literariamente, con elementos tan claros y sencillos, la aventura espiritual de un hombre que, sin renunciar a su fe originaria, el cristianismo, ha recibido del Islam una sabiduria que no afecta a su religión, sabiduría que le fue transmitida como una llave de liberación interior heredada de antiguas tradiciones a las que tuvo acceso durante su prisión en Argel entre 1575 y 1580 y en su viaje a Orán en 1581 " $"$.

11 Todas las citas entre comillas pertenecen al texto de L. E. TorD, que el mismo extrajo del manuscrito que encontró. 
Tales son estas notables revelaciones, nuevas e inéditas, sobre el verdadero personaje morisco, Cidi Hamete Ben Gelie, y su honda influencia islámica en el ilustre escritor Miguel de Cervantes. Cervantes compartió ampliamente su vida con musulmanes tanto hispanoandaluces como argelinos, de tal manera que no resulta extraño que su obra contenga muchos elementos de la civilización árabe-islámica: sociolingüísticos, místicos, etc., como conceptos y costumbres islámicos, refranes y adagios, arabismos, etc.

Por consiguiente, este homenaje de Cidi Hamete a Cervantes no es ni más ni menos que el debido y digno reconocimiento del maestro a su alumno. Reverencias y actamiento mutuos son aquí las grandes señales de una enseñanza tradicional islámica que pone siempre, en la escala superior, al profesor, a quien el discípulo debe manifestarle constantemente profundo respeto y gratitud, tal como aparece aquí. El honesto Cervantes había reconocido la valiosa enseñanza de los imames, como la del historiador arábigo Cidi Hamete Ben Gelie, quien, muy feliz de verse honrado e inmortalizado en esta obra de gran resonancia, rinde, a su vez, un esplendoroso homenaje a la grandeza del alma y valor de un humano genial y brillante como es Miguel de Cervantes.

El desenlace de esta historia de Hamete y su aparición hoy nos deja, también a nosotros, muy perplejos. El significado de la revelación es de tal importancia, que obliga a la reconsideración y al reexamen de la obra y de los estudios cervantinos, en el sentido de que la investigación deberá seguir otra dirección que profundice en las relaciones del Quijote con el mundo islámico. 